M. Yu. Golik, O. S. Kryskiv, A. M. Komissarenko, O. V. Kolisnyk

National University of Pharmacy

\title{
Molecular parameters and the antimicrobial activity of some $\mathrm{N}$-substituted amino acids
}

The concept of "drug likeness" is used when developing drugs for a potential biologically active substance, which must meet some specific criteria, in particular it should be bioavailable. The traditional method of "drug likeness" assessment is verification of compliance with Lipinski's rule.

Aim. To determine the compliance of the "drug likeness" concept for some N-substituted amino acids and identify the quantitative "structure - microbiological activity" relationships.

Materials and methods. Using ChemOffice 2016 software the physicochemical parameters determining the bioavailability of some $\mathrm{N}$-substituted amino acids were calculated. Determination of the possible correlations and quantitative ratios of the biological activity data experimentally obtained with the molar refraction (MR) values calculated was conducted using STATISTIKA 8 program.

Results and discussion. All compounds studied in their physicochemical properties meet the requirements for new BAS at the stage of testing their biological activity (correspond to Lipinski's rule). The dependence of the microbiological action of some $\mathrm{N}$-substituted amino acids on MR is maximal for compounds, which MR value is in the range of 2.13-4.53. The growth of all microorganisms was observed for unsubstituted amino acids (MR $<2.8)$. The maximum activity of all compounds studied was observed against gram-positive (B. subtilis and $S$. aureus), and the less activity was against gram-negative microorganisms (E. coli, P. vulgaris, $P$. aeruginosa) and fungi (C. albicans). It may be associated with the structural peculiarities of the cellular wall. The MR values calculated correlate satisfactorily with the experimental data of the antimicrobial activity of compounds.

Conclusions. Statistically significant values of MR correlation with the values of the antimicrobial activity of some $\mathrm{N}$-substituted amino acids against the microorganisms studied have been determined. It quantitatively confirms the presence of the "structure - activity" relationship in this series of compounds.

Key words: correlation; antimicrobial activity; N-substituted amino acids

М. Ю. Голік, О. С. Криськів, А. М. Комісаренко, О. В. Колісник

Молекулярні параметри та антимікробна активність деяких N-заміщених амінокислот

Концепція «drug likeness» використовується при розробці лікарських препаратів для того, щоб потенційна біологічно активна речовина відповідала певним критеріям, зокрема, була біодоступною. Традиційним методом оцінки «drug likeness» $є$ перевірка відповідності «правилам Ліпінські».

Мета даної роботи - встановлення відповідності концепції «drug likeness» деяких N-заміщених амінокислот та виявлення кількісних залежностей «структура - мікробіологічна активність».

Матеріали та методи. 3 використанням програмного пакету ChemOffice 2016 розраховані фрізико-хімічні параметри, що визначають біодоступність деяких N-заміщених амінокислот. Встановлення можливих кореляцій та кількісних співвідношень даних біологічної активності з розрахованими значеннями молярної рефрракції MR проведене з використанням програми STATISTIKA 8.

Результати та їх обговорення. Усі досліджені сполуки за сукупністю фрізико-хімічних властивостей задовольняють вимогам до нових БАР на стадії тестування їх біологічної активності (відповідають «правилу Ліпінські»). Залежність мікробіологічної дії деяких N-заміщених амінокислот від MR є максимальною для сполук, значення MR яких знаходиться у межах 2,13-4,53. Ріст усіх мікроорганізмів спостерігався для незаміщених амінокислот (MR < 2,8). Максимальна активність усіх досліджених сполук спостерігалась щодо грампозитивних (B. subtilis та S. aureus), менші - для грамнегативних мікроорганізмів (E. coli, P. vulgaris, P. aeruginosa) та грибів (C. albicans), що може бути пов'язане з особливостями будови клітинної стінки. Розраховані значення MR задовільно корелюють з експериментальними даними антимікробної активності.

Висновки. Встановлені статистично достовірні значення кореляції показника MR зі значеннями антимікробної дії деяких N-заміщених амінокислот стосовно досліджених мікроорганізмів, що кількісно підтверджує наявність зв'язку «структура-дія» у вказаному ряду сполук.

Ключові слова: кореляція; антибактеріальна дія; N-заміщені амінокислоти

Н. Ю. Голик, О. С. Крыськив, А. Н. Комиссаренко, Е. В. Колесник

\section{Молекулярные параметры и противомикробная активность некоторых $\mathrm{N}$-замещенных аминокислот}

Концепция «drug likeness» используется при разработке лекарственных препаратов для того, чтобы потенциальное биологически активное вещество соответствовало определенным критериям, в частности, было биодоступным. Традиционным методом оценки «drug likeness» является проверка соответствия «правилам Липински». 
Цель данной работы - установление соответствия концепции «drug likeness» некоторых N-замещенных аминокислот и установление количественных зависимостей «структура - микробиологическая активность».

Материалы и методы. С использованием программного пакета ChemOffice 2016 рассчитаны физико-химические параметры, определяющие биодоступность некоторых N-замещенных аминокислот. Установление возможных корреляций и количественных соотношений данных биологической активности с рассчитанными значениями молярной рефракции MR проведено с использованием программы STATISTIKA 8.

Результаты и их обсуждение. Все исследованные соединения по совокупности физико-химических свойств удовлетворяют требования к новым биологически активным веществам на стадии тестирования их биологической активности (отвечают «правилу Липински»). Зависимость микробиологического действия некоторых $\mathrm{N}$-замещенных аминокислот от MR является максимальной для соединений, значение MR которых находится в пределах 2,13-4,53. Рост всех микроорганизмов наблюдался для незамещенных аминокислот $(\mathrm{MR}<2,8)$. Максимальная активность всех исследованных соединений наблюдалась для грамположительных (B. subtilis и S. aureus), меньше - для грамотрицательных микроорганизмов (E. coli, P. vulgaris, P. aeruginosa) и грибов (C. albicans), что может быть связано с особенностями строения клеточной стенки. Рассчитанные значения MR удовлетворительно коррелируют с экспериментальными данными противомикробной активности.

Выводы. Установлены статистически достоверные значения корреляции показателя MR со значениями противомикробного действия некоторых N-замещенных аминокислот по отношению к исследованным микроорганизмам, что количественно подтверждает наличие связи «структура-действие» в данном ряду соединений.

Ключевые слова: корреляция; антибактериальное действие; N-замещенные аминокислоты

Determination of the "structure - activity" relationship is widely used in modern chemistry of biologically active compounds to predict their possible pharmacological activity [1].

At the present stage of development of combinatorial synthetic pharmaceutical chemistry millions of new compounds have been obtained. The classical ways for assessing their chemical and pharmacological properties are expensive, and their speed is less than the speed of discovering new compounds [2]. At present, prediction of the pharmacological properties at the initial stages of research attracts more attention. The quantitative "structure-activity" relationships (QSAR) are successfully used to study the mechanisms of action of different compounds [3]. They play an important role in predicting certain types of activities and are widely used in modern studies when it is required to describe rapidly a significant number of the compounds synthesized [4-6].

The concept of "drug likeness" is used when developing drugs for a potential biologically active substance, which must meet some specific criteria, in particular it should be bioavailable. The traditional method of "drug likeness" assessment is verification of compliance with Lipinski's rule [7].

Molar refraction (MR) reflects the volume of all molecules contained in one mole of the substance and cha-

Table 1

Data of the antimicrobial activity of compounds 1-12 [9]

\begin{tabular}{|c|c|c|c|c|c|c|c|}
\hline \multirow[b]{2}{*}{ No. } & \multicolumn{7}{|c|}{$\begin{array}{l}\text { The diameter of the growth inhibition zone, mm } \\
\text { (mean value)* }\end{array}$} \\
\hline & 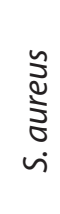 & ن & $\begin{array}{l}\frac{n}{3} \\
\frac{5}{5} \\
\frac{5}{3} \\
\dot{a}\end{array}$ & 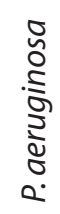 & 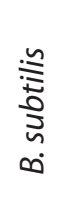 & 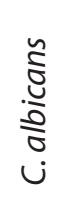 & 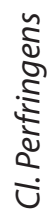 \\
\hline 1 & 2 & 3 & 4 & 5 & 6 & 7 & 8 \\
\hline 1 & 0 & 0 & 0 & 0 & 0 & 0 & 0 \\
\hline 2 & 24 & 15 & 18 & 22 & 24 & 19 & 22 \\
\hline 3 & 24 & 16 & 18 & 21 & 23 & 18 & 20 \\
\hline
\end{tabular}

racterizes the ability to polarization of all electrons located in it. It is practically independent of temperature and the aggregation state of a substance; therefore, it can be successfully used for determination of the dipole moments of molecules, the study of the molecular structure, formation of hydrogen bonds, etc. [8].

The aim of the work is to determine the compliance of the "drug likeness" concept for some N-substituted amino acids and identify the quantitative "structure microbiological activity" relationships.

\section{Materials and methods}

Previously [9] the microbiological activity of some $\mathrm{N}$-substituted amino acids 1-12 was studied (Tab. 1), the values of distribution coefficients for these compounds were calculated, then using the values obtained, the possible quantitative ratios were determined, and the "structure - activity" relationships revealed in this series with the experimental data of the antimicrobial activity were discussed [10].

To determine compliance with Lipinski's rule the physicochemical parameters determining the bioavailability of some N-substituted amino acids 1-12 (Tab. 2) were calculated using ChemOffice 2016 software, in particular Chem3D Ultra 16.0 [11].

Molar refraction is an important physicochemical parameter, which allows assessing the complex of proper-

Continuation of Table 1

\begin{tabular}{|c|c|c|c|c|c|c|c|}
\hline 1 & 2 & 3 & 4 & 5 & 6 & 7 & 8 \\
\hline 4 & 24 & 15 & 20 & 23 & 21 & 18 & 21 \\
\hline 5 & 0 & 0 & 0 & 0 & 0 & 0 & 0 \\
\hline 6 & 24 & 14 & 21 & 21 & 21 & 17 & 22 \\
\hline 7 & 23 & 14 & 20 & 20 & 20 & 15 & 23 \\
\hline 8 & 21 & 15 & 21 & 20 & 20 & 15 & 15 \\
\hline 9 & 0 & 0 & 0 & 0 & 0 & 0 & 0 \\
\hline 10 & 26 & 19 & 20 & 21 & 29 & 0 & 28 \\
\hline 11 & 26 & 18 & 21 & 22 & 30 & 0 & 30 \\
\hline 12 & 26 & 17 & 21 & 20 & 30 & 0 & 30 \\
\hline
\end{tabular}

*Note. 0 - the growth of microorganisms. 
Table 2

The calculated physicochemical parameters of some N-substituted amino acids

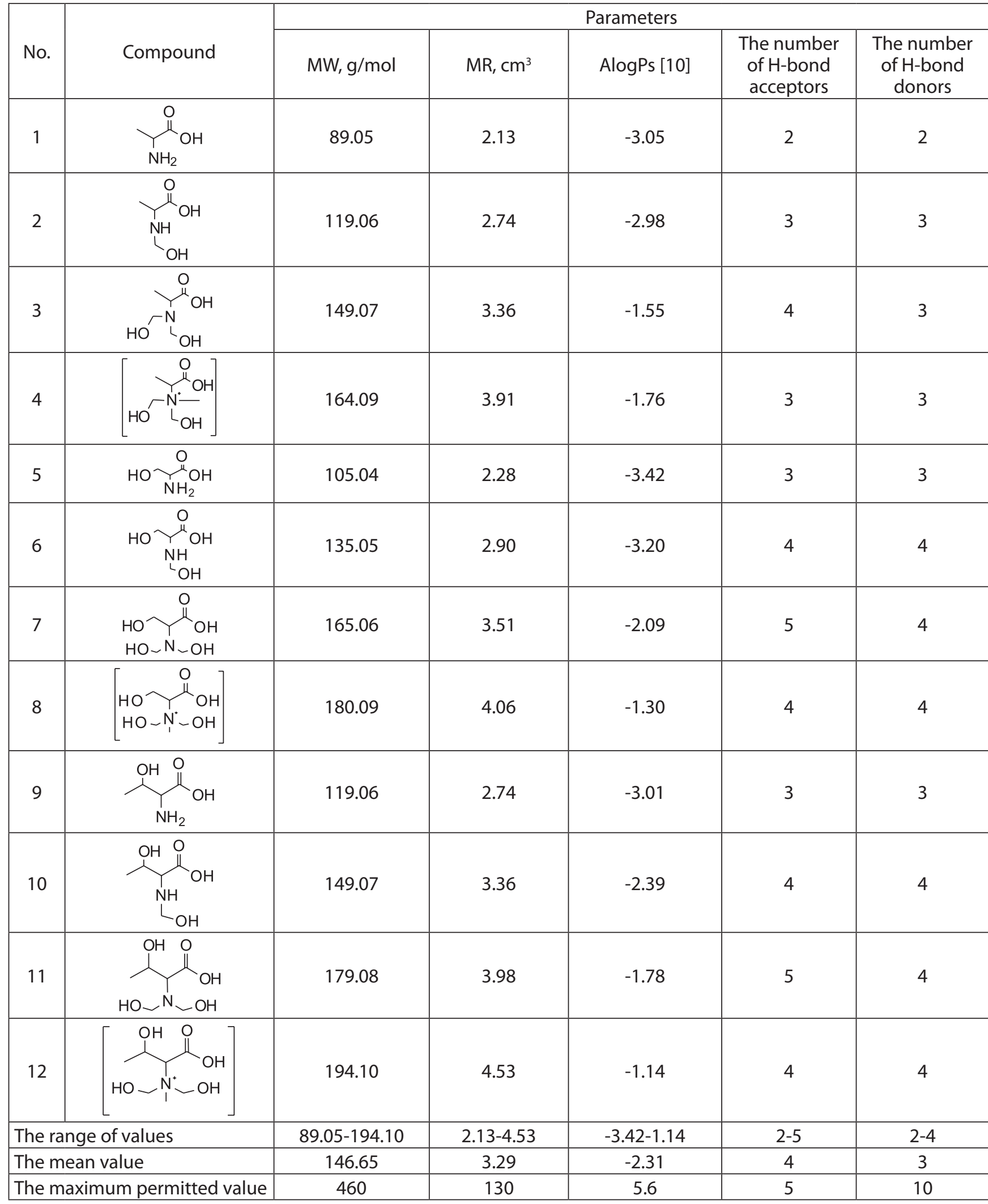

ties of a molecule and its potential bioavailability. Therefore, the next logical step was to determine the possible correlations and quantitative ratios of the biological activity data experimentally obtained with the MR values calculated (Tab. 1, 2). The statistical processing of the results was carried out using STATISTIKA 8 prog- ram [12]. According to the requirements of mathematical statistics the correlation coefficient indicates the closeness of the relationship between the signs: with values less than 0.3 - the relationship is absent, within the range of $0.3-0.7$ it is medium, and more than 0.7 it is strong [13]. 


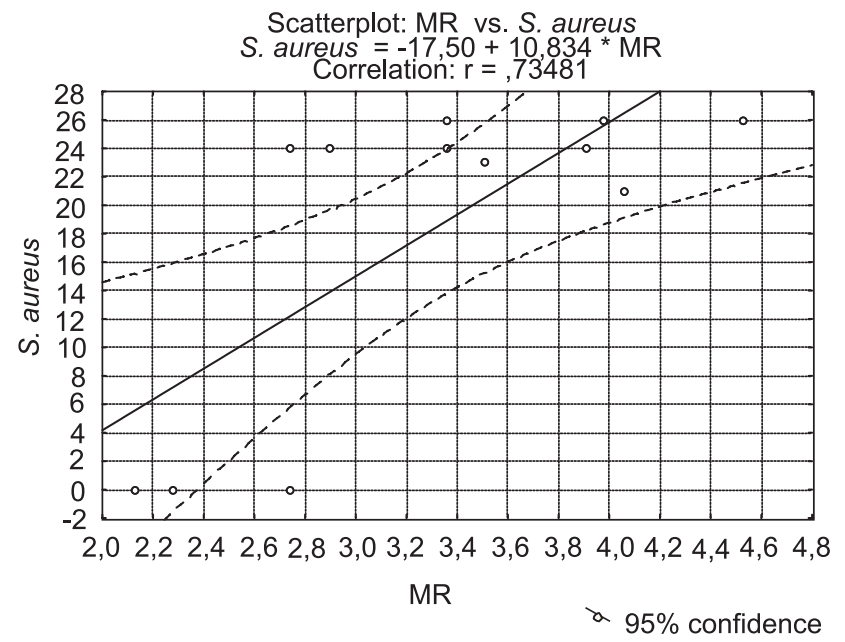

Fig. 1. Correlation of the antimicrobial action in relation to $S$. aureus and MR

\section{Results and discussion}

All compounds studied in their physicochemical properties meet the requirements for new BAS at the stage of testing their biological activity (correspond to Lipinski's rule) (Tab. 2).

In general, the statistical sampling included $12 \mathrm{com}-$ pounds. During the statistical processing of the research results when analyzing a sample with the length of 12 cases the values of Pearson correlation coefficients more than $0.40(\mathrm{p} \leq 0.05)$ are considered to be statistically significant [14].

The dependence of the microbiological action of compounds 1-12 on MR has a nonlinear character, and reaches the maximum values for compounds, which MR value is in the range close to the mean value (2.13-4.53) (Tab. 1, 2). The growth of all microorganisms was observed for unsubstituted amino acids (compounds 1, 5 and 9) with MR values less than 2.8. The maximum activity of all compounds studied was observed against gram-positive (B. subtilis and S. aureus), and the less activity was against gram-negative microorganisms (E. coli, $P$. vulgaris, $P$. aeruginosa) and fungi $(C$. albicans $)$. It

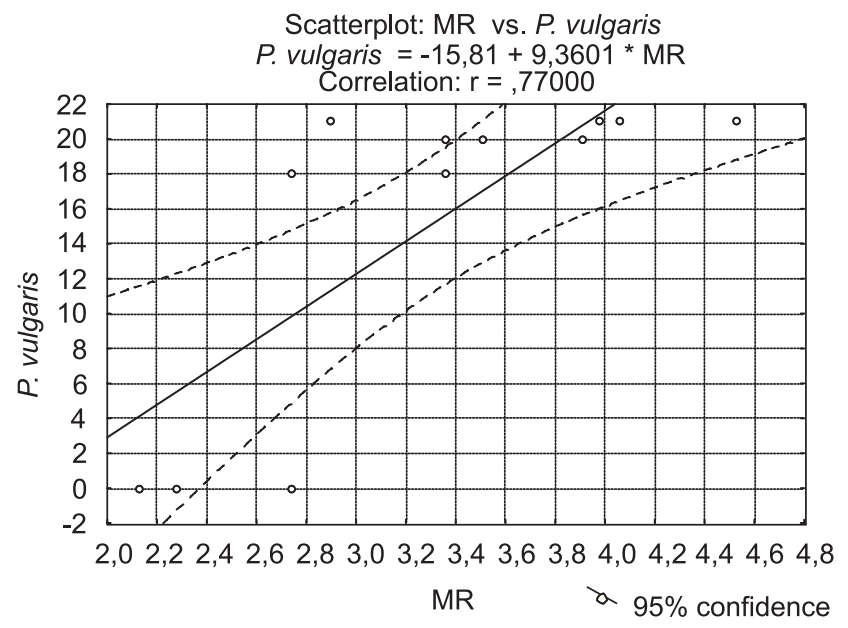

Fig. 3. Correlation of the antimicrobial action in relation to $P$. vulgaris and MR

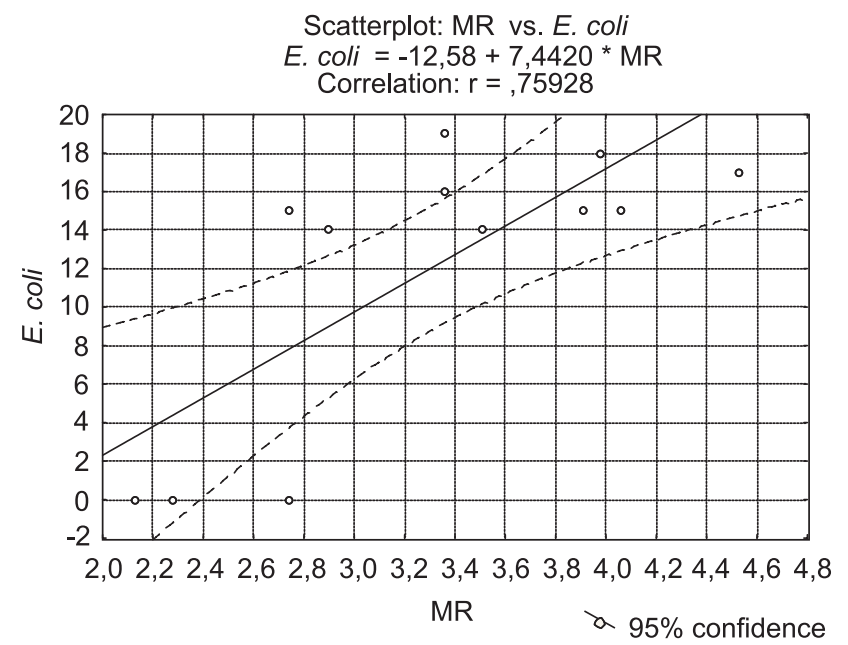

Fig. 2. Correlation of the antimicrobial action in relation to $E$. coli and MR

may be associated with the structural peculiarities of the cellular wall [15].

The analysis of the statistical processing of the results obtained indicates that the MR values calculated correlate satisfactorily (\%, negative values of correlation coefficients) with the experimental data of the antimicrobial activity of compounds 1-12 in relation to $S$. aureus $(\mathrm{r}=-0.73481)$, E. coli $(\mathrm{r}=-0.75928)$, P. vulgaris $(\mathrm{r}=-0.77000)$, . aeruginosa $(\mathrm{r}=-0.71342)$, B. subtilis $(\mathrm{r}=-0.76287)$, and Cl. Perfringens $(\mathrm{r}=-0.74181)$; they are statistically significant (Fig. 1-7). The relationship is absent only in the case of C. albicans $(\mathrm{r}=-0.13588)$, and its possible causes are mentioned above [15].

These combinations of Pearson correlation coefficient and the significance values indicate the reliability of plots 1-7 and equations given in Fig.

Therefore, the earlier considerations $[9,10]$ about the presence of the "structure - activity" relationship and the degree of its manifestation were confirmed quantitatively by calculations. The results obtained allow to predict the presence and the level of detection of the biological action of some $\mathrm{N}$-substituted amino acids and

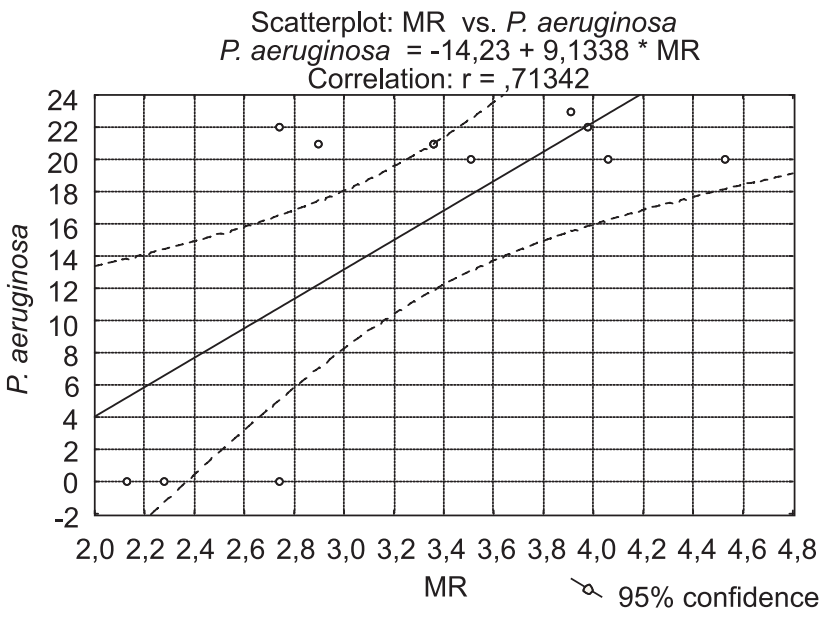

Fig. 4. Correlation of the antimicrobial action in relation to $P$. aeruginosa and MR 


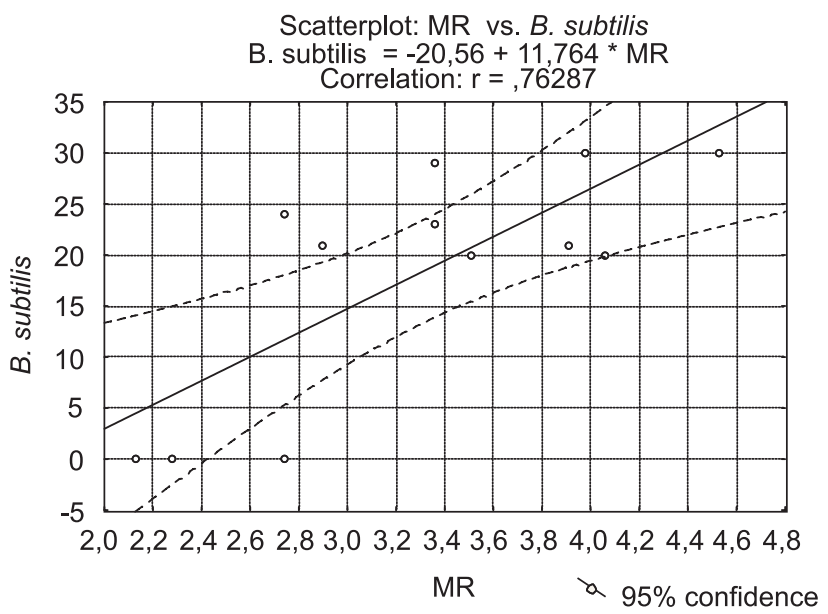

Fig. 5. Correlation of the antimicrobial action in relation to B. subtilis and MR

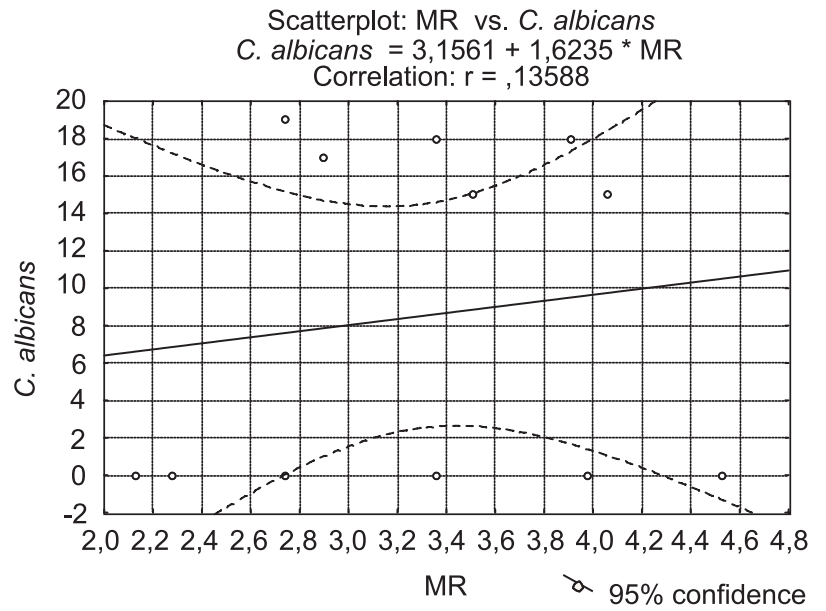

Fig. 6. Correlation of the antimicrobial action in relation to C. albicans and MR

to carry out a purposeful search of biologically active substances in the series.

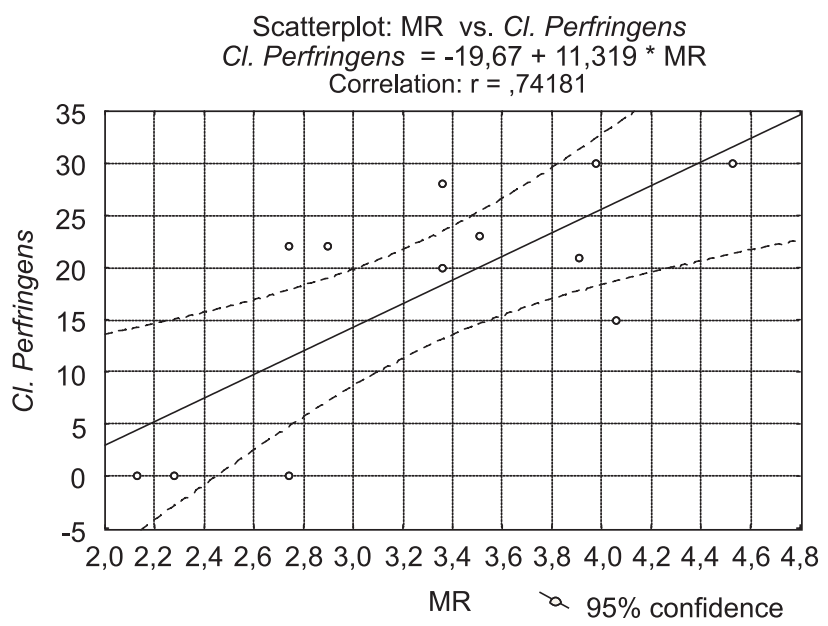

Fig. 7. Correlation of the antimicrobial action in relation to Cl. Perfringens and MR

\section{CONCLUSIONS}

1. Some N-substituted amino acids have been tested for compliance with the concept of "drug likeness". The results obtained have shown that the compounds can be recommended for further study as those that have favorable physicochemical parameters according to $\mathrm{Li}$ pinski's rule.

2. With the purpose of revealing QSAR the correlation and regression analysis of MR values calculated and the results of the experimental study of the antimicrobial activity of the compounds studied has been conducted.

3. Statistically significant values of MR correlation with the values of the antimicrobial activity of some N-substituted amino acids against $S$. aureus, E. coli, $P$. vulgaris, $P$. aeruginosa, $B$. subtilis and $C$. albicans have been determined. It quantitatively confirms earlier assumptions about the presence of the "structure - activity" relationship in this series of compounds and the degree of its manifestation.

Conflict of Interests: authors have no conflict of interests to declare.

\section{REFERENCES}

1. Quantifying the chemical beauty of drugs / G. R. Bickerton, G. V. Paolini, J. Besnard et al. // Nat. Chem. - 2012. - Vol. 4, Issue 2. P. 90-98. doi: 10.1038/nchem.1243

2. Srivastava, K. Molar refractivity based SAR/QSPR study of benzoic acid derivatives against mice in terms of median lethal dose / K. Srivastava, R. Mishra, A. Khan // IJRPC. - 2014. - Vol. 4, Issue 4. - P. 898-905.

3. Application of Chemical Models in Toxicological study / Y. Z. Sun, X. L. Yan, Z. J. Li, F. H. Meng // Chinese J. Environ. Health. - 2007. Vol. 24. - P. 734-736.

4. Putz, M. V. Introducing Spectral Structure Activity Relationship (S-SAR) Analysis. Application to Ecotoxicology / M. V. Putz, A.-M. Lacrama // Int. J. Mol. Sci. - 2007. - Vol. 8, Issue 5. - P. 363-391. doi: 10.3390/i8050363

5. Quantum-SAR Extension of the Spectral-SAR Algorithm. Application to Polyphenolic Anticancer Bioactivity / M. V. Putz, A.-M. Putz, M. Lazea et al. // Int. J. Mol. Sci. - 2009. - Vol. 10, Issue 3. - P. 1193-1214. doi: 10.3390/ijms10031193

6. The Application of QSAR in the Study of Chemicals Toxicity / F. H. Meng, Y. Z. Sun, Z. J. Li, X. L. Yan // Chem. Bioeng. - 2007. Vol. 24. - P. 5-7.

7. Lipinski, C. A. Lead-and drug-like compounds : the rule-of-five revolution / C. A. Lipinski // Drug Discovery Today : Technologies. 2004. - Vol. 1, Issue 4. - P. 337-341. doi: 10.1016/j.ddtec.2004.11.007

8. Padrón, J. A. Molecular descriptor based on a molar refractivity partition using Randic-type graph-theoretical invariant / J. A. Padrón., R. Carrasco, R. F. Pellón // J. Pharm. Pharmaceut. Sci. - 2002. - Vol. 5, Issue 3. - P. 258-266.

9. The search of compounds with the antimicrobial activity among derivatives of aliphatic $\alpha$-amino acids / A. N. Komissarenko, M. Yu. Golik, O. P. Osolodchenko et al. // The Sci. Heritage. - 2017. - Vol. 1, Issue 8. - P. 68-71.

10. The quantitative "structure - antibacterial activity" relationships in a series of N-substituted amino acids / M. Yu. Golik, O. S. Kryskiv, A. M. Komissarenko, O. V. Kolisnyk, K. I. Dudka // Вісник фармації. - 2017. - № 1 (89). - P. 14-20. doi: 10.24959/nphj.17.2153 
11. ChemOffice Professional. - Available at: https://www.cambridgesoft.com/Ensemble_for_Chemistry/ChemOffice/ChemOfficeProfessional

12. Statistica. - Available at : http://www.statsoft.com/Products/STATISTICA-Features

13. Бююль, A. SPSS : Искусство обработки информации. Анализ статистических данных и восстановление скрытых закономерностей : пер. с нем. / А. Бююль, П. Цёфель. - СПб. : ДиаСофтЮП, 2005. - 608 с.

14. Гублер, Е. В. Применение непараметрических критериев статистики в медико-биологических исследованиях / Е. В. Гублер, А. А. Генкин. - Л. : Медицина, 1973. - 141 с.

15. Brock Biology of Microorganisms / M. Madigan, J. Martinko, D. Stahl, D. Clark. - 13-th ed. - New York : Pearson Education, 2012. $1155 \mathrm{p}$.

\section{REFERENCES}

1. Bickerton, G. R., Paolini, G. V., Besnard, J., Muresan, S., Hopkins, A. L. (2012). Quantifying the chemical beauty of drugs. Nature Chemistry, 4 (2), 90-98. doi: 10.1038/nchem.1243

2. Srivastava, K., Mishra, R., Khan, A. (2014). Molar refractivity based SAR/QSPR study of benzoic acid derivatives against mice in terms of median lethal dose. IJRPC, 4 (4), 898-905.

3. Sun, Y. Z., Yan, X. L., Li, Z. J., Meng, F. H. (2007). Application of Chemical Models in Toxicological study. Chinese J. Environ. Health, 24, 734-736.

4. Putz, M. V., Lacrămă, A.-M. (2007). Introducing Spectral Structure Activity Relationship (S-SAR) Analysis. Application to Ecotoxicology. International Journal of Molecular Sciences, 8 (5), 363-391. doi: 10.3390/i8050363

5. Putz, M. V., Putz, A.-M., Lazea, M., Ienciu, L., Chiriac, A. (2009). Quantum-SAR Extension of the Spectral-SAR Algorithm. Application to Polyphenolic Anticancer Bioactivity. International Journal of Molecular Sciences, 10 (3), 1193-1214. doi: 10.3390/ijms10031193

6. Meng, F. H., Sun, Y. Z., Li, Z. J., Yan, X. L. (2007). The Application of QSAR in the Study of Chemicals Toxicity. Chem. Bioeng., 24, 5-7.

7. Lipinski, C. A. (2004). Lead- and drug-like compounds: the rule-of-five revolution. Drug Discovery Today: Technologies, 1 (4), $337-341$. doi: 10.1016/j.ddtec.2004.11.007

8. Padrón, J. A., Carrasco, R., Pellón, R. F. (2002). Molecular descriptor based on a molar refractivity partition using Randic-type graphtheoretical invariant. J. Pharm. Pharmaceut. Sci., 5 (3), 258-266.

9. Komissarenko, A. N., Golik, M. Yu., Osolodchenko, O. P., Leonova, S. G., Dudka, K. I. (2017). The search of compounds with the antimicrobial activity among derivatives of aliphatic 6-amino acids. The scientific heritage, 1 (8), 68-71.

10. Golik, M. Y., Kryskiv, O. S., Komissarenko, A. M., Kolisnyk, O. V., Dudka, K. I. (2017). The quantitative "structure - antibacterial activity" relationships in a series of N-substituted amino acids. Visnik Farmaciï, 1(89), 14-20. doi: 10.24959/nphj.17.2153

11. ChemOffice Professional. Available at: https://www.cambridgesoft.com/Ensemble_for_Chemistry/ChemOffice/ChemOfficeProfessional

12. Statistica. Available at: http://www.statsoft.com/Products/STATISTICA-Features

13. Biuiul, A., Tcefel, P. (2005). SPSS: Iskusstvo obrabotki informatcii. Analiz statisticheskikh dannykh i vosstanovlenie skrytykh zakonomernostei. SPb.: DiaSoftUP, 608.

14. Gubler, E. V., Genkin, A. A. (1973). Primenenie neparametricheskikh kriteriev statistiki v mediko-biologicheskikh issledovaniyakh. L.: Meditcina, 141.

15. Madigan, M., Martinko, J., Stahl, D., Clark, D. (2012). Brock Biology of Microorganisms, 13th Ed. New York: Pearson Education, 1155.

\section{Information about authors:}

Golik M. Yu., Candidate of Chemistry (Ph.D.), associate professor of the Analytical Chemistry Department, National University of Pharmacy.

E-mail: aptekar4009@qmail.com

Kryskiv O. S., Candidate of Pharmacy (Ph.D.), associate professor of the Inorganic Chemistry Department, National University of Pharmacy

Komissarenko A. M., Doctor of Pharmacy (Dr. habil.), professor of the Chemistry of Natural Compounds Department, National University of Pharmacy

Kolisnyk O. V., Candidate of Pharmacy (Ph.D.), associate professor of the Pharmaceutical Chemistry Department, National University of Pharmacy

Відомості про авторів:

Голік М. Ю., канд. хім. наук, доцент кафедри аналітичної хімії, Національний фармацевтичний університет. E-mail: aptekar4009@qmail.com

Криськів О. С., канд. фарм. наук, доцент кафедри неорганічної хімії, Національний фармацевтичний університет

Комісаренко А. М., д-р фарм. наук, професор кафедри хімії природних сполук, Національний фармацевтичний університет

Колісник О. В., канд. фарм. наук, доцент кафедри фармацевтичної хімії, Національний фармацевтичний університет

Сведения об авторах:

Голик Н. Ю., канд. хим. наук, доцент кафедры аналитической химии, Национальный фармацевтический университет. E-mail: aptekar4009@qmail.com

Крыськив О. С., канд. фарм. наук, доцент кафедры неорганической химии, Национальный фармацевтический университет

Комиссаренко А. Н., д-р фарм. наук, профессор кафедры химии природных соединений, Национальный фармацевтический университет

Колесник Е. В., канд. фарм. наук, доцент кафедры фармацевтической химии, Национальный фармацевтический университет 